\section{Regional differences in infection control conditions in a sample of primary health care services in Brazil}

\author{
Diferenças regionais nas condições de controle \\ de infecções em uma amostra de serviços de \\ atenção primária no Brasil
}

\section{Diferencias regionales en las condiciones del control de infecciones en una muestra de servicios de atención primaria en Brasil}

Mauro Henrique Nogueira Guimarães de Abreu 1 Vera Lúcia Silva Resende 1

Kyu Ha Lee 2

Antônio Thomaz Gonzaga da Matta-Machado 1 Jacqueline Rose Starr 2

doi: 10.1590/0102-311X00072416

\begin{abstract}
International guidelines have pointed out the importance of the physical environment of health care facilities in preventing and controlling infection. We aimed to describe the physical environment of dental care facilities in Brazil in 2014, focusing on characteristics designed to control infections. Exactly 16,202 dental offices in the Brazilian Unified National Health System (SUS) participated in this survey. Trained researchers extracted information about the infection control characteristics of health facilities by using a structured instrument. We used data from 12 dichotomous questions that evaluated the wall, floor, sink and tap conditions, and the presence and condition of sterilization equipment. We calculated a score by summing the number of characteristics handled appropriately for infection control, which could range from 0 to 12 . Hierarchical cluster analyses were developed. None of the 12 criteria were met by all the oral health teams. Only 208 (1.3\%) dental offices correctly performed all 12-infection control practices. Two clusters, with different frequencies of structure for infection control in dental offices, were identified. South and Southeast regions had the highest frequencies for Cluster 1, with better structure of infection control in dental offices. Dental care facilities of oral health teams were not typically meeting the infection control guidelines regarding clinic design and equipment. Adherence to the guidelines varied among the Brazilian geographic regions.
\end{abstract}

Delivery of Health Care; Primary Health Care; Infection Control

\author{
Correspondence \\ M. H. N. G. Abreu \\ Universidade Federal de Minas Gerais. \\ Av. Antônio Carlos 6627, Belo Horizonte, $M G$ \\ 31270-901, Brasil. \\ maurohenriqueabreu@gmail.com \\ 1 Universidade Federal de Minas Gerais, Belo Horizonte, Brasil \\ 2 The Forsyth Institute, Cambridge, U.S.A.
}




\section{Introduction}

International guidelines have pointed out the importance of the design, planning, construction, refurbishment, and maintenance of the physical environment of health care facilities for preventing and controlling infection 1,2 . However, reports about the physical environment of dental care settings are scarce in the literature; most of the research on infection control in dentistry has focused on the knowledge and practices of dentists and dental assistants. Lack of knowledge and low compliance to control infection practice in dentistry are some worrisome results in these surveys $3,4,5,6,7,8,9,10,11$. Studies, carried out in five towns from São Paulo State 12, and two towns, one from Espírito Santo State 13 and the other from Rio Grande do Sul State 14, Brazil, have shown that physical environment of dental care had problems regarding dental office sink, tap not draining properly, personal protective equipment, equipment for sterilization, among others.

In Belo Horizonte, capital of Minas Gerais State, Brazil, dental offices had frequent problems with personal protective equipment and equipment for sterilization 15 . A study carried out in a dental clinic from a Brazilian public university in Minas Gerais State have shown that the lack of physical barriers among dental offices has led to real possibility of cross-infection 16 .

In 2014, the Brazilian Ministry of Health led a second cycle of a program to assess and enhance the quality of primary health care (PHC), National Program for Improving Access and Quality of Primary Care (PMAQ-AB). This national survey of oral health teams in the Brazilian Unified National Health System (SUS) included evaluations of the physical environment of dental care clinics (http://dab. saude.gov.br/portaldab/ape_pmaq.php?conteudo=2_ciclo). According to the World Health Organization (WHO), the structure of health care facilities should be monitored on a national level. They also advise that basic organizational structure and building infrastructure are key factors for preventing and controlling endemic health care-associated infections and outbreaks 17.

Therefore, we aimed to describe the physical environment of dental care facilities of oral health teams in Brazil in 2014, focusing on characteristics designed to control infections. Secondarily, we described the frequency of adequate infection control practices in clinic design in different Brazilian regions and compared dental and medical clinic practices within the same health centers.

\section{Materials and methods}

\section{Ethics statement}

The study was submitted to and approved by the Brazilian Ethics Research Committee and by the Ethics Committee for Human Research of the Minas Gerais Federal University (protocol n. CAAE 02396512.8.0000.5149). We analyzed publicly available and anonymized data from the Brazilian Ministry of Health.

\section{Population}

We analyzed the second cycle of the PMAQ-AB (http://dab.saude.gov.br/portaldab/ape_pmaq. php? conteudo=2_ciclo). This survey was based on the classical quality of care framework by Donabedian, in which quality is evaluated using structure, process and outcome parameters 18 . Considering the importance of analyzing control infection practices on a national level 17 , we focused on these criteria in this study. Of 23,251 oral health teams in Brazil in January 2014, 19,946 (85.8\%) participated in this second cycle of PMAQ-AB. Of these, 2,433 (10.5\%) teams were excluded because they did not follow PMAQ recommendations, such as an adequate oral health surveillance system, presence of a dentist in the PHC unit, and dental equipment. Some PHC units included more than one oral health team. Exactly 16,202 dental offices, which included 17,513 oral health teams, were evaluated. All but 10 of these provided information about both oral health teams and their general medical (not dental) care. 


\section{Data collection}

Data were collected from November 2013 to April 2014. The observation instrument was developed through a partnership between the Brazilian Ministry of Health and a committee of six academic institutions throughout the country. The evaluation of each criterion was made by trained researchers, all with higher education in the health area. A pilot study was performed prior to the fieldwork. The survey was conducted by using computer tablets and a program designed specifically for the PMAQ-AB. Survey questions included photographs indicating the health services to be evaluated and criteria for the evaluation of each item, according to the Ministry of Health guidelines 1,19. The Ministry of Health assessed participation by telephone.

The questions were mostly dichotomous (yes/no). They evaluated dental office sink, sewage smell, tap not draining properly, personal protective equipment, sharps container, oven for sterilization, autoclave, floor and wall conditions, ventilation, and pack sealer. Some questions asked the number of pieces of a specific type of equipment; these responses were dichotomized (has at least one piece of such equipment - yes/no). Two originally separate questions about the presence of oven and autoclave were combined into one variable: "Presence of one oven for sterilization or one autoclave in good condition". There were two similar questions about the walls, floor, and ventilation, one regarding the dental office and the other regarding areas of the health center dedicated to general medical (not dental) care. For these two questions, we compared the proportion meeting the guidelines for the dental and non-dental areas of the clinic.

\section{Statistical analysis}

Each clinic setting received one point for each correct infection control criteria. Each clinic's score was the sum of the number of infection control criteria that were met (from 0 to 12). For example, if one clinic's score was 8 , it meant that this service had met eight infection control criteria. Although the SUS may have geographical differences in the quality of its services 20,21, for infection control, no previous results have shown any differences. Therefore, we used the multivariate agglomerative hierarchy technique and the between-groups linkage (average linkage) with squared Euclidian distances for the cluster analysis 22 . This exploratory data analysis technique, to organize observed data (in our case, from dental offices) into groups (clusters), is based on combinations of independent variables (in our case, structure for infection control in dental offices), and maximizes the similarity of cases within each cluster while maximizing the dissimilarity among groups. The clustering was based on the variables: presence of Personal Protective Equipment in sufficient quantity, presence of sharps container in sufficient quantity, presence of at least one oven for sterilization or one autoclave in good conditions, presence of at least one pack sealer in good conditions. The selection of these variables was based on the high risk of cross-infection of these parameters, as described in a previous study 13. Data reduction made the management of subgroups easier. In our study, three sets of clusters (two to four) were formed from the 16,202 dental offices, and the choice of two clusters was based on improved understanding of the phenomenon (the characteristics of infection control) 22. Finally, we compared the wall, floor and ventilation conditions between dental offices and non-dental areas in the health center, by calculating matched odds ratio (and 95\%CI). All the analyses were performed using SPSS for Windows version 19.0 (IBM Corp., Armonk, USA).

\section{Results}

For the 12 infection control criteria, the frequency with which criteria were met varied from $4.8 \%$ to $99 \%$. The criteria met in $>95 \%$ of clinics pertained to the sink, e.g., if it was unclogged and the tap draining properly. The rarest item among the recommended equipment in these Brazilian dental offices was a non-touch tap (Table 1).

Only 208 (1.3\%) of dental offices met all 12 infection control criteria. Most met at least half the criteria (Figure 1). Thirty-four clinics had scores lower than five, each clinic had scores of zero and one, two clinics had a score of two, and 12 and 18 clinics had scores of three and four, respectively 
Table 1

Prevalence of appropriate infection control equipment and physical environment in primary oral health care clinics. Brazilian Unified National Health System, 2013-2014 ( $=16,202)$.

\begin{tabular}{lcc}
\hline Infection control criteria * & $\mathbf{n}$ & $\%$ \\
\hline Clogged sink (no) & 16,075 & 99.2 \\
Useless sink (no) & 16,040 & 99.0 \\
Sewage smell (no) & 15,817 & 97.6 \\
Tap not draining properly (no) & 15,658 & 96.6 \\
Presence of Personal Protective Equipment in sufficient quantity (yes) & 14,901 & 92.0 \\
Presence of sharp container in sufficient quantity (yes) & 14,704 & 90.8 \\
Presence of mold in the sink (no) & 14,261 & 88.0 \\
Presence of at least one oven for sterilization or one autoclave in good condition (yes) & 13,585 & 83.8 \\
Does the dental office have good ventilation? (yes) & 13,402 & 82.7 \\
Are the floor and walls of the dental office smooth and do they have washable surfaces? (yes) & 10,986 & 67.8 \\
Presence of at least one pack sealer in good condition (yes) & 4,636 & 28.6 \\
Non-touch tap(s) (yes) & 783 & 4.8 \\
\hline
\end{tabular}

* The parenthetical responses indicate which response was given a point for meeting the given criterion.

\section{Figure 1}

Distribution of the scores on a survey of compliance with infection control recommendations conducted in Brazilian primary oral health care clinics, 2013-2014.

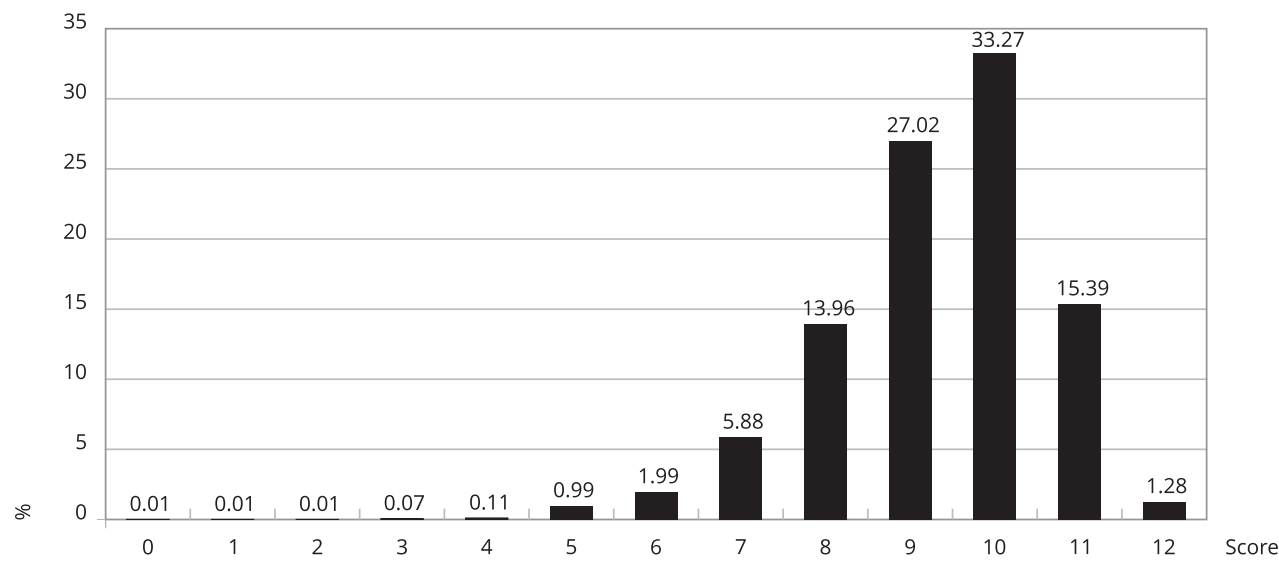

Note: the score was the number of criteria (out of 12) met for each clinic. Survey items focused on the physical environment, including wall and floor surfaces and sinks, and on the equipment available for sterilization, personal protection, and cleaning. Not visible in the figure, 34 dental clinics had scores lower than five, each one with scores of zero and one, two with a score of two, and 12 and 18 with scores of three and four, respectively.

(not visible in Figure 1). The first quartile and the median of this score were 9. The third quartile was 10. When we analyzed the dental offices with scores 9 and 10 ( $n=9,768 ; 60.3 \%)$, we identified that among these, $99.8 \%$ had no clogged sink, $99.6 \%$ presented no useless sink, $99 \%$ had no sewage smell, in $98.5 \%$ the tap was not draining properly, 96.1\% had Personal Protective Equipment in sufficient quantity, $95.2 \%$ had sharps containers in sufficient quantity, $93.7 \%$ had no mold in the sink, $87.6 \%$ had 
at least one oven for sterilization or one autoclave in good condition, in $89.6 \%$ the dental office had good ventilation, in $74.6 \%$ floor and walls of the dental office were smooth and had washable surfaces, $19.1 \%$ had at least one pack sealer in good condition, and $2.6 \%$ had non-touch tap.

Two clusters, with different frequencies of structure for infection control in dental offices, were identified. Cluster 1 ( $\mathrm{n}=15,124)$ included the OHTs with better structure compared with Cluster 2 ( $\mathrm{n}=1,078$ ). Of the Brazilian regions, South and Southeast regions had the highest frequencies for Cluster 1, with better structure of infection control in dental offices (Tables 2 and 3).

Compared with dental areas, non-dental areas in the health centers had 1.5 greater odds of floor and wall surfaces that were not smooth and washable (95\%CI: 1.4, 1.6). Non-dental areas in the health center also had 2.3 greater odds of having poor ventilation (95\%CI: 2.2, 2.5; Table 4).

\section{Table 2}

Presence of equipment for infection control accordingly to two clusters. Brazil, 2013-2014.

\begin{tabular}{|c|c|c|}
\hline Infection control criteria & Cluster $1(n=15,124)$ & Cluster $2(n=1,078)$ \\
\hline Presence of Personal Protective Equipment in sufficient quantity (yes) & $98.5 \%$ & $0.0 \%$ \\
\hline Presence of sharps containers in sufficient quantity (yes) & $92.2 \%$ & $70.7 \%$ \\
\hline Presence of at least one oven for sterilization or one autoclave in good condition (yes) & $85.0 \%$ & $68.2 \%$ \\
\hline Presence of at least one pack sealer in good condition (yes) & $30.5 \%$ & $2.2 \%$ \\
\hline
\end{tabular}

\section{Table 3}

Proportion of the two clusters according to Brazilian geographical regions in 2013-2014.

\begin{tabular}{lcc}
\hline Brazilian geographical regions & Cluster $\mathbf{1}(\mathbf{n}=\mathbf{1 5}, \mathbf{1 2 4})$ & Cluster 2 (n=1,078) \\
\hline North $(n=1,097)$ & $88.8 \%$ & $11.2 \%$ \\
Northeast $(n=7,199)$ & $92.3 \%$ & $7.7 \%$ \\
Central $(n=1,389)$ & $91.8 \%$ & $8.2 \%$ \\
Southeast $(n=4,256)$ & $94.9 \%$ & $5.1 \%$ \\
South $(n=2,261)$ & $96.9 \%$ & $3.1 \%$ \\
\hline
\end{tabular}

\section{Table 4}

Comparison between dental and non-dental areas of health centers regarding structural infection control practices. Brazil, $2013-2014$.

\begin{tabular}{|c|c|c|c|c|}
\hline \multirow[t]{2}{*}{ Infection control criteria } & & \multicolumn{2}{|c|}{ Health center } & \multirow[t]{2}{*}{ Matched OR $(95 \% \mathrm{Cl})$} \\
\hline & & Yes & No & \\
\hline \multicolumn{5}{|c|}{ Are the floor and walls smooth and washable? } \\
\hline \multirow[t]{2}{*}{ Dental office } & Yes & 7,963 & 3,018 & \multirow{2}{*}{$1.5(1.4,1.6)$} \\
\hline & No & 1,979 & 3,232 & \\
\hline \multicolumn{5}{|l|}{ Does it have good ventilation? } \\
\hline \multirow[t]{2}{*}{ Dental office } & Yes & 10,040 & 3,355 & \multirow{2}{*}{$2.3(2.2,2.5)$} \\
\hline & No & 1,441 & 1,356 & \\
\hline
\end{tabular}

95\% Cl: 95\% confidence interval; OR: odds ratio. 


\section{Discussion}

We evaluated compliance with 12 different recommendations regarding the physical environment and equipment for controlling the spread of infectious organisms in Brazilian dental health clinics in 2013-2014, the most recent survey available.

Among this large sample of $75 \%$ of primary oral health care clinics in Brazil, compliance with these criteria was far from ideal, and the degree of non-compliance varied across the different Brazilian regions. It is true that the dental offices were self-selected, which may have biased the results. Highly motivated teams that were more attentive to infection control practices were more likely to have joined the program, compliance could be even lower than that we observed in the sample. Over 2,400 of the $\sim 7,000$ non-participating clinics were excluded specifically because they were not compliant with the general PMAQ recommendations, which may also be not compliant with the recommendations considered here.

According to international protocols and scientific literature, ventilation is required because routine dental practice generates aerosols that can be contaminated with microorganism and chemicals 23 , and a well-functioning ventilation system dilutes the concentration of infectious aerosols 2 . The floor and walls should be smooth and washable to facilitate their disinfection 1,2,24. Routine cleaning is necessary to ensure that the environment is visibly clean and free of dust and soil. Ninety percent of microorganisms present visible dirt in health care settings 25. In the Brazilian clinics evaluated the high proportion of dental offices with poor ventilation or floor and walls that are not smooth or washable urges for investment on refurbishment to ensure the adequate protection of patients and dental staff.

The items with better compliance among the dental offices were those related to access to water and sewer in the dental office. For the most part, dental offices have functional sinks that can be operated properly. These characteristics are relevant because hand washing is considered one of the most important measures of infection control in health care settings 7,26 . However, the presence of mold in the sink of clinics and the near-absence of non-touch taps causes concern. The presence of water inside the sink contributes to the growth of microorganisms. The use of non-touch taps has been recommended 24,27 , despite seemingly conflicting data indicating that non-touch taps are a probable risk factor for Pseudomonas aeruginosa biofilm formation and subsequent transmission to patients 28 . Thus, if health services included non-touch taps, they would also need to be properly maintained 27.

The lack of sufficient personal protective equipment of dental offices also causes concern. Without sufficient personal protective equipment, the oral health team might opt not to treat patients rather than to put clinicians at risk. These conditions may limit the access of patients to the already insufficiently accessible dental treatment in the Brazilian health system 29,30,31, or put professionals and patients at biological risks 1,24, if they treat patients without proper protection.

A high percentage of the dental offices had sterilization equipment, yet there were offices that lacked any such equipment, and the majority lacked a pack sealer in good condition. It is possible that sterilization occurred outside the clinic in a centralized sterilization facility. Nevertheless, there are some advantages to providing sterilization on-site in health centers ${ }^{32}$, such as efficiency, safety and costs. Because we did not have data to discern this possibility, further study should be conducted to identify whether the lack of such an important equipment in dental settings is an indicator of low quality.

The final criterion assessed concerned waste management, and most health teams had sufficient access to sharps containers for disposal of this type of biohazard waste.

Only a small percentage of dental offices complied with all 12 recommended practices. This result calls for more investment in the physical infrastructure of PHC in Brazil. Both patients and dental staff appear to be routinely at risk of cross-infection in dental health-care settings 17 . Despite being not very big, the regional differences in the distribution of frequencies of clusters demonstrated the same trends identified in another previous evaluation of PHC in Brazil 20. The planning of healthcare facilities should also consider these inequalities so that more resources are applied in the regions with worse conditions.

For the two criteria that could be assessed outside the dental offices, adequacy of the floors, walls, and ventilation were similar in the dental areas and for most health centers. When compliance dif- 
fered, it was much more common that the dental clinics were more compliant than other areas of the health center, probably because oral health care has just recently been integrated into primary health centers in Brazil, i.e., the dental facilities are newer and possibly more up-to-date on environmental infection control practices ${ }^{33}$. A similar integration between dental care and medical care in PHC has taken place in other countries 34,35 .

Some important environmental infection control practices were not evaluated by this survey, such as access to ultrasonic cleaners, disinfectants, antiseptics and more detailed information about personal protective equipment (e.g., gloves, masks, etc.). It is important to highlight that the descriptive approach in this research does not allow an evaluation of factors associated with the identified problems. Moreover, we are not able to objectively define the reliability and reproducibility of each measurement made by the trained researchers in this survey. Although we do not rank the relative importance of each infection control criterion, we selected the variables for the cluster analysis based on their high risk of cross-infection 13. Despite these limitations, this is the most comprehensive evaluation of the environmental infection control practices in oral health clinics conducted in Brazil, and it is likely that no other country has conducted a survey of this size. Our results are quite similar to the local evaluations of structure of infection control in dental offices made in Brazilian small towns 12,13,14 and Belo Horizonte 15. As far as it was possible to review the scientific literature, we did not identify other similar large empirical studies. Even in countries where clinics are supposed to meet these criteria in order to operate, as it is the case of Brazil and other countries 1,24, our results indicate the need for frequent audits 36 .

Despite the indisputable advances in dental health policies in Brazil recently 33 , this evaluation suggests that even more effort will be required to provide and maintain adequate infection control environments and equipment in Brazilian oral health clinics. The continued audit of these criteria is advised both in Brazil and internationally.

\section{Contributors}

M. H. N. G. Abreu was responsible for the acquisition of data and for organizing the dataset, conceived and designed the study, responsible for analysis and interpretation of data; contributed to the writing of the manuscript revising it critically for important intellectual content, and approved the final version. V. L. S. Resende and J. R. Starr conceived and designed the study, analysis and interpretation of data; contributed to the writing of the manuscript revising it critically for important intellectual content, and approved the final version. K. H. Lee and A. T. G. Matta-Machado were responsible for the acquisition of data and for organizing the dataset, analysis and interpretation of data, contributed to the writing of the manuscript revising it critically for important intellectual content, and approved the final version.

\section{Acknowledgments}

To Brazilian Graduate Studies Coordinating Board (Capes; grant number 2462-15-0), Brazilian National Research Council (CNPq) and Minas Gerais State Research Foundation (Fapemig) for the financial support.

\section{References}

1. Kohn WG, Collins AS, Cleveland JL, Harte JA, Eklund KJ, Malvitz DM, et al. Guidelines for infection control in dental health-care settings: 2003. MMWR Recomm Rep 2003; 52(RR17):1-61.

2. Department of Health. Health Building Note 00-09: infection control in the built environment. London: Department of Health; 2013.

3. Barlean L, Danila I, Balcos C, Saveanu I, Balan A. Preventive attitudes towards infection transmission in dental offices in North-East Romania. Rev Med Chir Soc Med Nat Iasi 2012; 116:1209-12.

4. Budnyak MA, Gurevich KG, Fabrikant KG, Miller K, Puttaiah R. Dental infection control and occupational safety in the Russian Federation. J Contemp Dent Pract 2012; 13:703-12.

5. Cleveland JL, Bonito AJ, Corley TJ, Foster M, Barker L, Gordon Brown G, et al. Advancing infection control in dental care settings: factors associated with dentists' implementation of guidelines from the Centers for Disease Control and Prevention. J Am Dent Assoc 2012; 143:1127-38.

6. Duffy RE, Cleveland JL, Hutin YJ, Cardo D. Evaluating infection control practices among dentists in Valcea, Romania, in 1998. Infect Control Hosp Epidemiol 2004; 25:570-5. 
7. Myers R, Larson E, Cheng B, Schwartz A, Da Silva K, Kunzel C. Hand hygiene among general practice dentists: a survey of knowledge, attitudes and practices. J Am Dent Assoc 2008; 139:948-57.

8. November-Rider D, Bray KK, Eklund KJ, Williams KB, Mitchell TV. Massachusetts dental public health program directors practice behaviors and perceptions of infection control. J Dent Hyg 2012; 86:248-55.

9. Su J, Deng XH, Sun Z. A 10-year survey of compliance with recommended procedures for infection control by dentists in Beijing. Int Dent J 2012; 62:148-53.

10. Yuzbasioglu E, Sarac D, Canbaz S, Sarac YS, Cengiz S. A survey of cross-infection control procedures: knowledge and attitudes of Turkish dentists. J Appl Oral Sci 2009; 17:565-9.

11. Abreu MH, Lopes-Terra MC, Braz LF, Rímulo AL, Paiva SM, Pordeus IA. Attitudes and behavior of dental students concerning infection control rules: a study with a 10 -year interval. Braz Dent J 2009; 20:221-5.

12. Ten CY, Pereira AC, Daruge E. Avaliação das condições sanitárias dos estabelecimentos de assistência odontológica, consultório odontológico tipo I. Rev Paul Odontol 2001; 23:4-10.

13. Frazão P, Bortolotti MGLB. Desigualdades nas condições de controle de infecção em consultórios odontológicos em município brasileiro. Cad Saúde Pública 2006; 22:965-74.

14. Cabreira FS. Biossegurança em consultórios odontológicos públicos no município de Alegrete - RS: uma avaliação de estrutura [Dissertação de Mestrado]. Pelotas: Universidade Federal de Pelotas; 2010.

15. Costa MC. As condições de controle de infecção dos estabelecimentos odontológicos fiscalizados pela Secretaria Municipal de Saúde de Belo Horizonte: uma abordagem epidemiológica [Dissertação de Mestrado]. Belo Horizonte: Universidade Federal de Minas Gerais; 2002.

16. Discacciati JA, Sander HH, Castilho LS, Resende VL. Verificação de respingos durante o trabalho do cirurgião-dentista. Rev Panam Salud Pública 1998; 3:84-7.

17. World Health Organization. Core components for infection prevention and control programmes. Report of the Second Meeting Informal Network on Infection Prevention and Control in Health Care. Geneva: World Health Organization; 2008.

18. Donabedian A. Evaluating the quality of medical care. Milbank Q 2005; 83:691-729.

19. Departamento de Atenção Básica, Secretaria de Atenção à Saúde, Ministério da Saúde. Manual de estrutura física das unidades básicas de saúde. Brasília: Ministério da Saúde; 2006.

20. dos Reis CMR, da Matta-Machado ATG, do Amaral JHL, Werneck MAF, de Abreu M. Describing the primary care actions of oral health teams in Brazil. Int J Environ Res Public Health $2015 ; 12: 667-78$.
21. Martins RC, Reis CM, Matta Machado AT, Amaral JH, Werneck MA, Abreu MH. Relationship between primary and secondary dental care in public health services in Brazil. PLoS One 2016; 11:e0164986.

22. Johnson RA, Wichern DW. Applied multivariate statistical analysis. Upper Saddle River: Pearson Prentice Hall; 2007.

23. Kadaifciler DG, Cotuk A. Microbial contamination of dental unit waterlines and effect on quality of indoor air. Environ Monit Assess 2014; 186:3431-44.

24. Australian Dental Association. Guidelines for infection control. 3rd Ed. St. Leonards: Australian Dental Association; 2015.

25. Ducel G, Fabry J, Nicolle L. Prevention of hospital-acquired infections. Valletta: World Health Organization; 2002.

26. Canham L. The first step in infection control is hand hygiene. Dent Assist 2011; 80:42-6.

27. Jumaa PA. Hand hygiene: simple and complex. Int J Infect Dis 2005; 9:3-14.

28. Loveday HP, Wilson JA, Kerr K, Pitchers R, Walker JT, Browne J. Association between healthcare water systems and Pseudomonas aeruginosa infections: a rapid systematic review. J Hosp Infect 2014; 86:7-15.

29. Cunha MA, Lino PA, Santos TR, Vasconcelos M, Lucas SD, Abreu MH. A 15-year time-series study of tooth extraction in Brazil. Medicine (Baltimore) 2015; 94:e1924.

30. Esteves RS, Mambrini JV, Oliveira AC, Abreu MH. Performance of primary dental care services: an ecological study in a large Brazilian city. ScientificWorldJournal 2013; 2013:176589.

31. Pinto RS, Roncalli AG, Abreu MH, Vargas AM. Use of public oral health services by the adult population: a multilevel analysis. PLoS One 2016; 11:e0145149.

32. Acosta-Gnass SI, Stempliuk VA. Sterilization manual for heath centers. Washigton DC: PanAmerican Health Organization; 2009.

33. Pucca Jr. GA, Gabriel M, de Araujo ME, de Almeida FC. Ten years of a national oral health policy in Brazil: innovation, boldness, and numerous challenges. J Dent Res 2015; 94: 1333-7.

34. Health Resources and Services Administration. Integration of oral health and primary care practice. Rockville: Health Resources and Services Administration; 2014.

35. Gambhir RS. Primary care in dentistry: an untapped potential. J Family Med Prim Care 2015; 4:13-8.

36. Care Quality Commission. A fresh start for the regulation and inspection of primary care dental services: working together to change how we regulate primary care dental services. Newcastle: Care Quality Commission; 2014. 


\section{Resumo}

As diretrizes internacionais destacam a importância do ambiente físico dos serviços de saúde para prevenir e controlar as infecções. Procuramos descrever o ambiente físico em serviços de saúde bucal no Brasil em 2014, com enfoque nas características programadas para controlar as infecções. Precisamente 16.202 consultórios odontológicos no Sistema Único de Saúde (SUS) participaram na pesquisa. Pesquisadores treinados coletaram informações sobre as características do controle de infecções nesses serviços de saúde, utilizando um instrumento padronizado. Utilizamos dados de 12 perguntas dicotômicas que avaliavam as condições das paredes, piso, pia e torneira e a presença e as condições do equipamento de esterilização. Calculamos um escore pela soma do número de características administradas adequadamente para o controle de infecções, variando de 0 a 12. Foram desenvolvidas análises hierárquicas de clusters. Nenhum dos 12 critérios foi atendido por todas as equipes de saúde bucal. Apenas 208 (1,3\%) dos consultórios odontológicos realizavam todas as 12 práticas de controle de infecções. Foram identificados dois clusters com distintas frequências de estruturas para controle de infecções nos consultórios odontológicos. As regiões Sul e Sudeste mostraram as maiores frequências no Cluster 1, com melhor estrutura de controle de infecções nos consultórios odontológicos. De maneira geral os serviços de saúde bucal não atendiam as diretrizes para o controle de infecções, referentes à planta física e equipamento dos consultórios. A aderência às diretrizes variava de acordo com a região do país.

Assistência à Saúde; Atenção Primária à Saúde; Controle de Infecções

\section{Resumen}

Las directrices internacionales destacan la importancia del ambiente físico de los servicios de salud para prevenir y controlar infecciones. Procuramos describir el ambiente físico en servicios de salud bucal en Brasil en 2014, centrándonos en las características programadas para controlar las infecciones. Precisamente 16.202 consultorios odontológicos del Sistema Único de Salud (SUS) participaron en la investigación. Investigadores entrenados recogieron información sobre las características del control de infecciones en esos servicios de salud, utilizando un instrumento estandarizado. Utilizamos los datos procedentes de 12 preguntas dicotómicas que evaluaban las condiciones de las paredes, suelo, fregadero y grifo, además de la existencia y condiciones del equipamiento de esterilización. Calculamos una puntuación para la suma del número de características administradas adecuadamente para el control de infecciones, variando de 0 a 12. Se desarrollaron análisis jerárquicos de clúster. Ninguno de los 12 criterios fue observado por todos los equipos de salud bucal. Solamente 208 (1,3\%) de los consultorios odontológicos realizaban las 12 prácticas de control de infecciones al completo. Se identificaron dos clústeres con distintas frecuencias de estructuras para el control de infecciones en los consultorios odontológicos. Las regiones Sur y Sudeste mostraron las mayores frecuencias en el Clúster 1, con una mejor estructura de control de infecciones en los consultorios odontológicos. De manera general, los servicios de salud bucal no atendian a las directrices para el control de infecciones, referentes a las instalaciones físicas y equipamiento de los consultorios. La adherencia a las directrices variaba de acuerdo con la región del país.

Prestación de Atención de Salud; Atención Primária de Salud; Control de Infecciones
Submitted on 29/Apr/2016

Final version resubmitted on $08 / \mathrm{Feb} / 2017$

Approved on 20/Feb/2017 